Anna Carlissa P. Arriola, MD

Antonio H. Chua, MD

Rosario Jessica F. Tactacan-Abrenica, MD

'Department of Otorhinolaryngology

Head and Neck Surgery

Jose R. Reyes Memorial Medical Center

${ }^{2} H I V$ Department

San Lazaro Hospital Manila
Correspondence: Dr. Antonio H. Chua

Department of Otorhinolaryngology - Head and Neck Surgery

4th Floor, Jose R. Reyes Memorial Medical Center

Rizal Avenue, Sta. Cruz, Manila 1003

Philippines

Phone: (632) 7436921 ; (632) 7119491 local 320

Email: entjrrmmc@yhoo.com

Reprints will not be available from the authors.

The authors declare that this represents original material that is not being considered for publication elsewhere in full or in part, in print or electronic media; that the manuscript has been read and approved by all the authors, that the requirements for authorship have been met by each author, and that each author believes that the manuscript represents honest work. Disclosures: The authors signed disclosures that there are no financial or other (including personal) relationships, intellectual passion, political or religious beliefs, and institutional affiliations that might lead to a conflict of interest.

Presented at the Philippine Society of Otolaryngology Head and Neck Surgery Analytical Research Contest (First Place), Hall A Unilab Bayanihan Center, Pioneer St. Brgy Kapitolyo, Pasig City, October 23, 2014

\section{Otorhinolaryngologic Manifestations of Human Immunodeficiency Virus Infection in Manila, the Philippines}

\begin{abstract}
Objective: To determine the prevalence of otorhinolaryngologic (ENT) manifestations in people living with Human Immunodeficiency Virus (HIV) infection seen in our institutions and to determine the association of these manifestations with age, sex, CD4 count and antiretroviral treatment.
\end{abstract}

\section{Methods:}

\section{Design: Cross-sectional Study \\ Setting: Two Tertiary Government Hospitals}

Subjects: $\quad$ Adult patients ( $>19$ years old) confirmed to be HIV- infected were seen at Jose R. Reyes Memorial Medical Center and San Lazaro Hospital from February to July 2014. A data sheet regarding ENT manifestations was filled upon examination. Age, sex, CD4 count and antiretroviral treatment data were recorded. Independent samples t-test was used to determine age association with manifestations. Fischer's exact test was used to determine association of sex and manifestations. Chi-square test of independence was used to determine association of CD4 count and antiretroviral treatment with manifestations. Association was considered statistically significant if $p<0.05$.

Results: Three hundred one (301) patients participated with 287 males (95.3\%) and 14 females (4.7\%). The mean age was $31.7 \pm 8$. One hundred ninety seven (197 or $65.4 \%$ ) had ENT manifestations. The most common areas of manifestations came from the oral cavityoropharyngeal area ( $n=104,37 \%)$, nasal cavity-nasopharyngeal area $(n=73,26 \%)$ and ear $(n=43$, 15\%). The most frequent manifestations were cervical lymphadenopathy, aphthous stomatitis and acute rhinitis. There was no significant difference in the age $(p=0.31)$ and sex $(p=0.15)$ of patients with and without manifestations. However, there was a direct association of manifestations with low $C D 4$ count $(p<0.001)$ and inverse association with antiretroviral treatment $(p=0.036)$.

Conclusion: Our findings emphasize the importance of screening for ENT manifestations, regular CD4 monitoring and enrollment to antiretroviral therapy in persons with HIV. Baseline otorhinolaryngologic examination upon HIV diagnosis and prior to initiating treatment should be followed by regular surveillance. Conversely, physicians should also be aware that patients with ENT manifestation may have HIV infection.

Keywords: HIV, Otorhinolaryngologic diseases, CD4 Lymphocyte Count, Anti-Retroviral Agents, Stomatitis, Rhinitis

Philipp J Otolaryngol Head Neck Surg 2015; 30 (2): 8-12

(C) Philippine Society of Otolaryngology - Head and Neck Surgery, Inc. 
Human immunodeficiency virus (HIV) infection has been increasing in the Philippines. From 2010 to 2013, newly-diagnosed HIV cases increased from 1,591 to 4,814, with 2,951 newly-reported cases from February to July 2014.' Studies have found that over $80 \%$ of HIV-infected individuals present with otorhinolaryngologic symptoms during the course of infection. ${ }^{2}$ The onset of opportunistic infections in HIV-positive patients is generally associated with a low CD4 count. ${ }^{3}$ Highly active antiretroviral therapy has greatly improved the control of the immune-deficiency while reducing the number of otorhinolaryngological manifestations. ${ }^{4}$

Otorhinolaryngologists should take an active role in the holistic management of HIV infected persons. Despite studies in other countries regarding ENT manifestations seen in HIV patients, limited studies have been conducted to determine HIV-associated otorhinolaryngologic manifestations in the Philippines.

This paperaims to determine the prevalence of otorhinolaryngologic manifestations in HIV-infected patients in Manila, and to determine the associations of otorhinolaryngologic manifestations with age, sex, CD4 count and antiretroviral treatment.

\section{METHODS}

This was a cross-sectional study conducted at the HIV Department of the San Lazaro Hospital and the Department of Otorhinolaryngology Head and Neck Surgery of the Jose R. Reyes Memorial Medical Center, both located in Manila, the Philippines.

The target population was HIV-infected patients diagnosed by the HIV Department, above 19 years old, and seen at the Department of Otorhinolaryngology Head and Neck Surgery from February to July 2014.

The study protocol and informed consent were reviewed and approved by the Research and Ethics Review Committee of our institutions. An Infectious Disease specialist oriented the Ear, Nose, Throat (ENT) examiner on HIV counseling and confirmed diagnosis of HIV-infected patients. All patients that were seen by the Infectious Disease specialist were referred to the ENT examiner for evaluation. After obtaining informed consent, 301 patients were seen by the ENT examiner.

A clinical history was obtained and physical examination conducted for each patient. Examination instruments included an otoscope, tuning fork, nasal speculum, laryngeal mirror and rigid endoscope which were disinfected according to standard protocol. ${ }^{5} \mathrm{~A}$ data sheet regarding ENT manifestations was completed after each examination and an assessment made. The independent variables (age, sex, CD4 count and antiretroviral treatment) were recorded. The dependent variable was presence or absence of ENT manifestations.
Mean and standard deviation were computed to summarize age and sex of the subjects. The statistical analysis was carried out through PASW Statistics for Microsoft Windows Version 18.0 (SPSS Inc., Chicago, USA). Independent samples t-test was used to determine the association of age in patients with or without manifestations. Fischer's exact test was used to determine association of sex with manifestations. CD4 count was categorized according to CD4 levels based on immunosuppression. ${ }^{6}$ Chi-square test of independence with Cramer's V test was used to determine association of CD4 count among those with and without manifestations. Chi-square test of independence with Phi was used to determine association of antiretroviral treatment among those with and without manifestations. $P$ values of less than 0.05 were considered significant.

\section{RESULTS}

Three hundred one patients (301) participated with 287 males (95.3\%) and 14 females (4.7\%). Ages ranged from 20 to 59 . The mean age was $31.7 \pm 8$.

Of the 301 patients, 197 (65.4\%) had ENT manifestations. The mean age of patients with ENT manifestations was 31.4 (SD 7.86) compared to the mean age of patients without ENT manifestations of 32.4 (SD 8.30) which was not statistically significant (t-test $1.02, p=0.31$, two-tailed). Otorhinolaryngologic manifestations were present among 185/287 males $(64.5 \%)$ and $12 / 14$ females (85.7\%). There was no statistical significance in presence of ENT manifestations among males and females. (Fischer's exact test $p=0.15$ ).

Of the 284 ENT manifestations found (Table 1), the most to least common groups of manifestations were oral cavity-oropharyngeal, nasal cavity-nasopharyngeal, ear, head and neck and laryngeal. (Figure 1) Overall, the most frequent manifestations were cervical lymphadenopathy (9.8\%), aphthous stomatitis $(9.5 \%)$ and acute rhinitis (7.3\%). Among otologic manifestations, chronic otitis media was the most common. Laryngopharyngeal reflux was the most common laryngeal manifestation.

In terms of severity of HIV status, ENT manifestations were seen in 16 patients categorized as "Not with Significant Immunosuppression" (CD4 >/=500 cell/ul), 26 patients with "Mild Immunosuppression" (CD4 350-499 cell/ul ), 39 patients with "Advanced Immunosuppresion" (200-349 cell/ul) and 115 patients with "Severe Immunosuppression" ( $<200 \mathrm{cell} / \mathrm{ul}$ ). CD4 count and ENT manifestations were found to have a direct association that was statistically significant, $\left(X^{2}=35.42 ; p<0.001\right.$; Cramers's V $=0.34$ ).

Among patients without antiretroviral therapy, 27/33 presented with ENT manifestations compared to the $170 / 268$ patients with antiretroviral therapy. Antiretroviral treatment and manifestations were inversely associated and statistically significant $\left(X^{2}=4.39 ; p=0.036 ; \Phi=-0.12\right.$.). 
Table 1. ENT Manifestations and their frequencies encountered in our study.

\begin{tabular}{|c|c|c|c|c|c|c|c|c|c|}
\hline \multicolumn{2}{|l|}{ Otologic } & \multicolumn{2}{|l|}{$\begin{array}{c}\text { Nasal cavity- } \\
\text { Nasopharyngeal }\end{array}$} & \multicolumn{2}{|l|}{$\begin{array}{c}\text { Oral cavity- } \\
\text { Oropharyngeal }\end{array}$} & \multicolumn{2}{|l|}{ Laryngeal } & \multicolumn{2}{|l|}{ Head and Neck } \\
\hline Chronic otitis media & 7 & Acute rhinitis & 21 & Aphthous stomatitis & 27 & $\begin{array}{l}\text { Laryngopharyngeal } \\
\text { reflux }\end{array}$ & 11 & $\begin{array}{l}\text { Chronic lymphadeno- } \\
\text { pathy }\end{array}$ & 28 \\
\hline $\begin{array}{l}\text { Chronic suppurative } \\
\text { otitis media }\end{array}$ & 6 & Nonallergic rhinitis & 15 & Oral candidiasis & 20 & Acute laryngitis & 5 & Acute lymphadenitis & 4 \\
\hline Acute otitis externa & 6 & Allergic rhinitis & 12 & Acute pharyngitis & 10 & Ulcer & 3 & $\begin{array}{l}\text { Bilateral parotid } \\
\text { enlargement }\end{array}$ & 2 \\
\hline $\begin{array}{l}\text { Sensorineural } \\
\text { hearing loss }\end{array}$ & 5 & Acute rhinosinusitis & 9 & $\begin{array}{l}\text { White hairy } \\
\text { leukoplakia }\end{array}$ & 9 & Leukoplakia epiglottis & 2 & Preseptal cellulitis & 1 \\
\hline Otomycosis & 3 & Chronic rhinosinusitis & 7 & Acute tonsillopharyngitis & 7 & Chronic laryngitis & 1 & $\begin{array}{l}\text { Acute Bacterial } \\
\text { Parotitis }\end{array}$ & 1 \\
\hline $\begin{array}{l}\text { Acute suppurative } \\
\text { otitis media }\end{array}$ & 3 & $\begin{array}{l}\text { Epistaxis secondary to } \\
\text { manipulation }\end{array}$ & 2 & Exfoliative cheilitis & 5 & Vocal fold paralysis & 1 & $\begin{array}{l}\text { Consider Branchial } \\
\text { cleft cyst }\end{array}$ & 1 \\
\hline $\begin{array}{l}\text { Benign paroxysmal } \\
\text { positional vertigo }\end{array}$ & 3 & Crusting & 2 & Hyperemic soft palate & 4 & Vocal fold polyp & 1 & Parotid Abscess & 1 \\
\hline Acute otitis media & 2 & Vitiligo & 1 & Odontogenic infection & 3 & & & Lymphoma & 1 \\
\hline $\begin{array}{l}\text { Chronic otitis } \\
\text { externa, psoriasis }\end{array}$ & 2 & $\begin{array}{l}\text { Hyperemic nasal } \\
\text { mucosa }\end{array}$ & 1 & Pigmented tongue & 3 & & & $\begin{array}{l}\text { Multiple cystic masses } \\
\text { (forehead,sub- } \\
\text { mandibular area, } \\
\text { parietal area) }\end{array}$ & 1 \\
\hline $\begin{array}{l}\text { Eustachian tube } \\
\text { dysfunction }\end{array}$ & 2 & Nasal vestibulitis & 1 & $\begin{array}{l}\text { Chronic tonsillar } \\
\text { hypertrophy }\end{array}$ & 3 & & & & \\
\hline $\begin{array}{l}\text { Conductive hearing } \\
\text { loss }\end{array}$ & 2 & Adenoid hypertrophy & 1 & $\begin{array}{l}\text { Median rhomboid } \\
\text { glossitis }\end{array}$ & 2 & & & & \\
\hline $\begin{array}{l}\text { Otitis media with } \\
\text { effusion }\end{array}$ & 1 & Nasal polyp & 1 & Petechiae palate & 2 & & & & \\
\hline \multirow[t]{10}{*}{ Kaposi's sarcoma } & 1 & & & Atrophic glossitis & 1 & & & & \\
\hline & & & & $\begin{array}{l}\text { Leukoplakia, } \\
\text { hardpalate }\end{array}$ & 1 & & & & \\
\hline & & & & $\begin{array}{l}\text { Erythematous } \\
\text { vermillion }\end{array}$ & 1 & & & & \\
\hline & & & & $\begin{array}{l}\text { Telangectasia } \\
\text { hard palate }\end{array}$ & 1 & & & & \\
\hline & & & & Angular cheilitis & 1 & & & & \\
\hline & & & & Erosive glossitis & 1 & & & & \\
\hline & & & & Fissured tongue & 1 & & & & \\
\hline & & & & Oral herpes & 1 & & & & \\
\hline & & & & TMJ dysfunction & 1 & & & & \\
\hline & 43 & & 73 & & 104 & & 24 & & 40 \\
\hline
\end{tabular}


Table 2. Association of Age, Sex, CD4 count and Anti-retroviral treatment with ENT Manifestations.

\begin{tabular}{|c|c|c|c|c|}
\hline & & $\begin{array}{c}\text { Without } \\
\text { Manifes- } \\
\text { tations }\end{array}$ & $\begin{array}{c}\text { With } \\
\text { Manifes- } \\
\text { tations }\end{array}$ & $p$ value \\
\hline Age & Mean SD & $32.4 \pm 8.30$ & $31.4 \pm 7.86$ & 0.31 \\
\hline \multirow[t]{2}{*}{ Sex } & Female & 2 & 12 & \multirow[t]{2}{*}{0.15} \\
\hline & Male & 102 & 185 & \\
\hline \multirow{4}{*}{ CD4 count } & $<200$ cell/ul & 24 & 115 & \multirow{4}{*}{$<0.001$} \\
\hline & 200-349 cell/ul & 40 & 39 & \\
\hline & 350-499 cell/ul & 24 & 26 & \\
\hline & $>/=500$ cell/ul & 17 & 16 & \\
\hline \multirow{2}{*}{$\begin{array}{l}\text { Antiretroviral } \\
\text { (ARV) Therapy }\end{array}$} & $\begin{array}{l}\text { Without ARV } \\
\text { Treatment }\end{array}$ & 6 & 27 & \multirow{2}{*}{0.036} \\
\hline & $\begin{array}{l}\text { With ARV } \\
\text { Treatment }\end{array}$ & 98 & 170 & \\
\hline
\end{tabular}

\section{DISCUSSION}

This study showed that $65 \%$ of subjects with HIV, $64.5 \%$ of males and $85.7 \%$ of females had ENT manifestations. Although ENT manifestations may have been present prior to or during HIV infection, their high prevalence in our sample emphasizes the pivotal role of the otorhinolaryngologist in managing HIV patients.

The most common areas involved were the oral cavityoropharyngeal followed by the nasal cavity-nasopharyngeal and the ear. Cervical lymphadenopathy, aphthous stomatitis and acute rhinitis were the most prevalent manifestations. These parallel findings of other studies that showed oropharyngeal and cervical lymphadenopathy as predominant manifestations. ${ }^{2}$

A study of oral manifestations found the most common oral lesions were candidiasis, hairy leukoplakia, recurrent aphthous-like ulcerations, Kaposi's sarcoma, herpes simplex infection, herpes zoster infection, warts and periodontal diseases. ${ }^{7}$ Our study showed that aphthous stomatitis was the most common oral manifestation followed by oral candidiasis. Other oral manifestations seen in this study were hairy leukoplakia, exfoliative cheilitis, odontogenic infection and median rhomboid glossitis.

Acute rhinitis was the most common nasal manifestation in our study. Some patients noted recurrent acute rhinitis. Disruption in the immune system and loss of allergic control may lead to the development of frequent acute rhinitis, allergic rhinitis and nonallergic rhinitis. HIV infection depresses the immune system and may explain the presence of rhinitis in this population. On the other hand, some patients had a history of allergic rhinitis prior to HIV diagnosis and not all patients with

\section{ENT Manifestations $(\mathbf{N}=\mathbf{2 8 4})$}

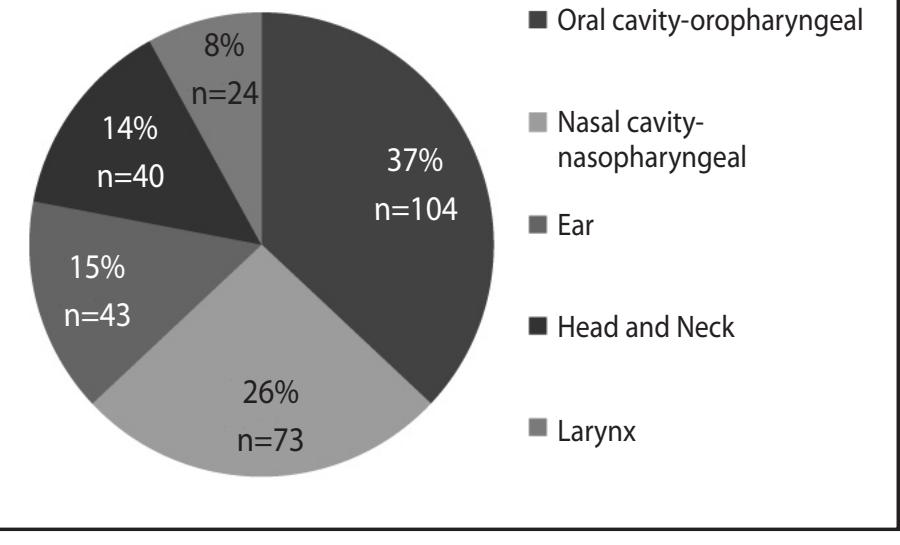

Figure 1

rhinitis should be suspected to have HIV.

Chronic otitis media was the most common otologic manifestation in this study. One presented with sensorineural hearing loss after an episode of meningitis while another was diagnosed after tuberculosis treatment. An HIV-associated malignancy, Kaposi's sarcoma of the auricle presented with a black lesion in one patient. Otitis externa and suppurative otitis media were also observed. These reflect the findings of a study by Moazzez et al. that demonstrated otitis externa, otitis media, Kaposi's sarcoma and sensorineural hearing loss as common ear manifestations. ${ }^{8}$ Otologic symptoms may not be the direct effect of HIV alone but result from a combination of the effects of HIV infection with opportunistic microorganisms and/or possible ototoxic effects of certain therapeutic agents. ${ }^{4}$

A previous study found an association between age and male sex with otological manifestations. ${ }^{9}$ No such association was found in our study. However, the large disparity between the number of male and female subjects in our sample could have affected our findings. That the majority of our participants were male may reflect the incidence of HIV in the Philippines occuring predominantly in males with the predominant type of transmission being through males having sex with other males.'

A significant association between CD4 count and ENT manifestations was seen in our study. The CD4 count is an immunological parameter that is used to monitor the burden of HIV. The CD4 count categorization used in this study was based on the World Health Organization Immunological staging of HIV infection. ${ }^{6}$ Although ENT manifestations were evident even in patients without significant immunosuppression, 
more patients who were severely immunosuppressed presented with ENT manifestations than those who were not significantly immunosuppressed. (Table 2) A direct association of ENT manifestations with low CD4 count $(p<0.001)$ was observed. Similar studies have described oral manifestations such as candidiasis to be significantly associated with low CD4 count. ${ }^{3}$ Opportunistic infection in the ears, nose and throat could reflect a decreased CD4 count. On the other hand, the ENT manifestations may project the immunosuppression status of the patient. A cohort study could be recommended to establish causality of manifestations and CD4 count.

A significant inverse association between antiretroviral treatment and manifestation was recognized $(p=0.036)$, consonant with previous studies. An antiretroviral regimen has been associated with higher mean CD4 count and lower prevalence of chronic rhinosinusitis ${ }^{10}$ and chronic otitis media. ${ }^{11}$ Another study observed a significant decrease in the incidence of oral infections after triple antiretroviral therapy. ${ }^{4}$ Antiretroviral therapy is efficient in reducing the viral load of HIV and increasing CD4 count. ${ }^{4}$ Although antiretroviral treatment may decrease ENT manifestations, antiretroviral treatment may also be a precursor to other ENT manifestations. Further studies may determine ENT adverse effects of antiretroviral therapy.

Our study only saw 301 out of the 18,923 documented cases in the Philippines. ${ }^{1}$ Moreover, HIV infected persons possess different levels of immune severity. Our study represented the status of severity at the time of examination based on the CD4 count. We were only able to determine the prevalence of ENT manifestations and the association of ENT manifestations with age, sex, CD4 count and antiretroviral therapy in these particular patients at a definite place and time context. Other limitations of our study include a lack of baseline (pre-HIV infection) history of ENT manifestations and ENT examination, noninclusion of duration and transmission of HIV infection or duration of ENT manifestations, non-consideration of CD4 count patterns and length of enrollment to antiretroviral therapy and specific therapeutic combinations.

The association of CD4 count and antiretroviral treatment with ENT manifestations emphasizes the importance of regular monitoring and enrollment to antiretroviral therapy. The degree of ENT manifestations present in HIV patients warrant vigilance through baseline otorhinolaryngologic examination upon HIV diagnosis and prior to initiating treatment. This should then be followed by regular surveillance. With the rising incidence of HIV in the Philippines, physicians should also be aware that patients with ENT manifestation may have HIV.

\section{ACKNOWLEDGEMENTS}

The authors would like to thank Dr. Samantha S. Castañeda for her guidance and the H4 Staff of San Lazaro Hospital for their valuable assistance.

\section{REFERENCES}

1. National HIV-AIDS and STI strategic information and surveillance unit. Philippine HIV/AIDS registry July 2014. National Epidemiology Center, Department of Health Manila Philippines. [cited 2014 Aug 21] Available from:http://www.pnac.org.ph/uploads/documents/publications/ NEC HIV July-AIDSreg2014.pdf.

2. Prasad HK, Bhojwani KM, Shenoy V. HIV manifestations in otolaryngology. Am J Otolaryngol [serial on the Internet]. 2006 [cited 2013 Sept 11];27:179-185. Available from:http://www.ncbi. nlm.nih.gov/pubmed/16647982.

3. Davoodi P, Hamian M, Nourbaksh R, Motamayel FA. Oral Manifestations Related to CD4 Lymphocyte Count in HIV-Positive Patients. J Dent Res Dent Clin Dent Prospects. 2010; 4(4):115119.

4.Campanini A, Marani M, Mastroianni A, Cancellieri C, Vicini C. Human immunodeficiency virus infection: personal experience in changes in head and neck manifestations due to recent antiretroviral therapies. Acta Otorhinolaryngol Ital. 2005 February; 25(1): 30-35.

5. Rutala WA, Weber DJ, Healthcare Infection Control Practices Advisory Committee. Guidelines for Disinfection and Sterilization in Healthcare Facilities,2008. [ cited 2013 Sept 9] Available from http://www.cdc.gov/hicpac/pdf/guidelines/disinfection_nov_2008.pdf.

6. Interim WHO Clinical Staging of HIV/AIDS and HIV/AIDS Case Definitions for Surveillance. [cited 2013 Sept 9] Available from:www.who.int/hiv/pub/guidelines/clinicalstaging.pdf.

7. Baccaglini L, Atkinson JC, Patton LL, Glick M, Ficarra G, Peterson DE. Management of oral lesions in HIV-positive patients.Oral Surg Oral Med Oral Pathol Oral Radiol Endod. 2007 Mar;103 Suppl:S50.e1-23.

8. Moazzez AH, Alvi A. Head and neck manifestations of AIDS in adults. Am Fam Physician.1998 April 15:57(8):1813-22

9. Jafari S, Razmpa E, Saeedinejad Z, Sadrhosseini M, Paydary K. Otolaryngological Manifestations in HIV Infected Patients, Tehran, Iran. J AIDS Clinic Res .2012;3:160

10. Neto $C D P$, Weber $R$, Araújo-Filho $B C$, Miziara ID. Rhinosinusitis in HIV-infected children undergoing antiretroviral therapy. Rev. Bras. Otorrinolaringol [serial on the Internet] 2009 Feb[cited 2014 Sep 13]; 75(1): 70-75. Available from: http://www.scielo.br/scielo. php?script=sci_arttext\&pid=S0034-72992009000100011\&lng=en. http://dx.doi.org/10.1590/ S0034-72992009000100011.

11. Weber R, Neto CDP, Miziara ID, Araújo-Filho BC. HAART impact on prevalence of chronic otitis media in Brazilian HIV-infected children. Rev. Bras. Otorhinolaringol. [serial on the Internet]. 2006 [cited 2014 Sep 13];72(4):509-14. Available from: http://www.scielo.br/pdf/rboto/v72n4/ en_a12v72n4.pdf 